\title{
ANALISIS YURIDIS KRIMINOLOGIS TENTANG KEKERASAN DALAM RUMAH TANGGA YANG DILAKUKAN OLEH ISTRI TERHADAP SUAMI
}

\author{
Oleh: \\ Zulkarnain*
}

\begin{abstract}
Household violence is a serious phenomenon that should be catered for due to its seriousness; it is not only done by the husband, who its mostly the doer of the action, but also by the wife. As a result, it is urgent to put the laws forbidingthe practice of such a householdviolence into effect. The laws control the protection of the victims in a household. Paradoxically, the enforcement, however, may trigger new modes of household violence, namely the violence done by the wife. The modes of violence are various in type.

In criminology studies, it is shown that the violence by the wife is caused by many causes. Further analyses (using a causalteit theory in criminal law) suggest that the violence by the wife is marely a negative reaction against the violence by the husband. On the basis of such of phenomenon, the law enforcement underscores socio-criminological aspects in order to realize a criminal individualization-based justice. Making a wife into a criminal case as a form of a repressive action of the violence just hide the real forms of household violence mostly done by the husband.
\end{abstract}

Kata kunci: Kekerasan dalam rumah tangga, kekerasan istri, penegakan hukum

\section{PENDAHULUAN}

Pada dasarnya, sebagaimana dikemukakan oleh Kalibonso, ${ }^{1}$ bahwa kekerasan dalam rumah tangga bisa saja dilakukan oleh setiap anggota keluarga terhadap siapa saja dari anggota keluarganya, baik oleh suami/bapak, isteri/ibu, anak, saudara, pembantu, dan anggota keluarga lainnya. Akan tetapi, dari hasil penelitian Farha Ciciek menemukan fakta bahwa kebanyakan korban kekerasan dalam rumah tangga adalah isteri. ${ }^{2}$ Demikian juga dari hasil penelitian yang

${ }^{*}$ Zulkarnain adalah dosen pada Fakultas Hukum Universitas Widyagama Malang

${ }^{1}$ Kalibonso, "Kekerasan terhadap Perempuan dalam Rumah Tangga sebagai Pelanggaran Hak Asasi Manusia" dalam Luhalima (Ed.) Pemahamam terhadap Bentuk-bentuk Kekerasan terhadap Perempuan dan Alternatif Pemecahannya. Kelompok Kerja Convention Watch Pusat Kajian Wanita dan Fewleral. Jakarta, 2000, hal. 109 sudah dilakukan di beberapa daerah maupun beberapa negara di dunia, menunjukkan bahwa kekerasan dalam rumah tangga paling banyak dilakukan oleh suami/bapak terhadap isteri dan anak-anaknya. Bahkan sebuah penelitian yang dilakukan di Inggris dan Amerika Utara, menyimpulkan bahwa kekerasan domestik terjadi pada setiap satu dari empat keluarga, dan bahwa satu dari sepuluh perempuan mengalami kekerasan dari pasangan hidupnya. ${ }^{3}$

\footnotetext{
${ }^{2}$ Farha Ciciek, Ikhtiar Mengatasi Kekerasan dalam Rumah Tangga. LKAJ-PSP-The Asia Fondation. Jakarta, 1999, hal. 22

${ }^{3}$ New Shout Wales Child Protection Council, Child Abuse and Domestic Violence: A Child Protection Perspective. Author. Sydney, 1996, hal. 5
} 
Banyaknya kasus kekerasan dalam rumah tangga yang terjadi menunjukkan adanya perubahan sosial yang perlu dikaji penyebabnya. Lebih-lebih pada beberapa tahun terakhir ini ketika persoalan krisis ekonomi melilit hampir seluruh rumah tangga di Indonesia. Khususnya di Malang dan Bojonegoro (selanjutnya menjadi lokasi penelitian ini) misalnya, pernah beberapa kali diberitakan terjadi tindak pidana yang dilakukan oleh anggota keluarganya sendiri. Pada awal bulan maret 2007 masyarakat Kota Malang digegerkan oleh ulah seorang isteri (ibu rumah tangga) yang tega membunuh empat anaknya dan kemudian melakukan bunuh diri. ${ }^{4}$ Tahun sebelumnya sempat dimuat dimedia cetak, bahwa seorang isteri tega memotong alat kelamin suaminya karena suaminya diduga selingkuh dengan perempuan lain, dan masih banyak kasus serupa lainnya.

Selain di kota Malang, peneliti menemukan fakta bahwa di Kabupaten Bojonegoro Jawa Timur, selama dua tahun terakhir telah terjadi sedikitnya 4 kasus pembunuhan yang dilakukan oleh seorang isteri terhadap suami dengan berbagai alasan dan motif tindak pidananya. ${ }^{5} \mathrm{Hal}$ tersebut sungguh memprihatinkan, karena justru terjadi dalam lingkup keluarga yang semestinya harus hidup rukun damai berdasarkan ikatan lahir batin untuk menjadi keluarga yang harmonis. Oleh karena itu, patut kita bertanya, mengapa fenomena kekerasan dalam rumah tangga ini sering terjadi? Tetapi mengapa juga banyak kasus kekerasan dalam keluarga yang tidak bisa terselesaikan secara adil dan bijaksana sesuai dengan hak-hak hukum masing-masing anggota keluarga?

${ }^{4}$ Lihat Jawa Pos, 12 Maret 2007

${ }^{5}$ Erdino Trihandoyo, Penegakan Hukum terhadap Pelaku Kekerasan Dalam Rumah Tangga yang Dilakukan oleh Isteri terhadap Suami. Fakultas Hukum Univ. Widyagama. Malang, 2007, hal. 34
Kekerasan dalam rumah tangga seringkali dianggap sebagai persoalan pribadi (domestik) yang harus diselesaikan secara pribadi pula antara mereka yang bertikai. Bahkan meskipun kekerasan ini sering mengakibatkan cacat atau meninggalnya korban, kasus tersebut biasanya dimasukkan sebagai kriminal biasa. Itu pun akan bisa diproses melalui jalur hukum apabila salah satu anggota keluarga yang dirugikan mengadukannya kepada kepolisian. Sementara yang terjadi, sangat jarang masyarakat yang melaporkan kekerasan dalam rumah tangga ini kepada polisi karena menganggap hal itu adalah persoalan pribadi keluarganya.

KDRT merupakan salah satu penyebab kekacauan dalam masyarakat. Penganiayaan adalah suatu perbuatan yang dilakukan dengan sengaja, yang ditujukan untuk menimbulkan rasa sakit atau luka pada tubuh orang lain yang akibat mana semata-mata merupakan tujuan sistem informasi petindak. ${ }^{6}$ Berbagai temuan penelitian memastikan bahwa kekerasan dalam rumah tangga tidak berhenti pada penderitaan korban saja. Rentetan penderitaan itu, akan menular ke luar lingkup rumah tangga dan selanjutnya mewarnai kehidupan masyarakat juga.

Keluarga merupakan lembaga sosial yang paling dasar untuk mencetak kualitas manusia, sampai saat ini masih menjadi keyakinan dan harapan bersama bahwa keluarga senantiasa dapat diandalkan sebagai lembaga ketahanan moral, akhlak, al karimah dalam konteks bermasyarakat, bahkan baik buruknya generasi suatu bangsa ditentukan pula oleh pembentukan pribadi dalam keluarga. Disinilah keluarga memiliki peranan yang strategis untuk memenuhi harapan tersebut. ${ }^{7}$

\footnotetext{
"Farha Ciciek, Op. Cit. hal. 23

"Ch Mufidah, "Paradigma Gender". Bayumedia Publishing. Malang, 2004, hal 122
}

64 | Analisis Yuridis Kriminologis.. 
Akhir-akhir ini, peristiwa kekerasan yang dilakukan oleh seorang suami terhadap isteri, dipandang bukanlah suatu hal yang luar biasa. Hal ini menunjukkan bahwa kekerasan yang dilakukan suami terhadap isteri adalah hal yang biasa terjadi. Namun, apabila terjadi peristiwa seorang isteri membunuh suaminya sendiri, barulah dianggap sebagai suatu yang luar biasa dan butuh proses berfikir panjang untuk menelaahnya secara komprehensif.

Penganiayaan atau bahkan pembununan yang dilakukan oleh seorang isteri terhadap suaminya sendiri merupakan fenomena spesifik yang sangat jarang terjadi. Oleh karena itu, apabila sampai peristiwa tersebut terjadi, berarti telah terjadi faktor penyebab yang sangat kuat pengaruhnya sehingga seorang isteri sampai melakukan perbuatan kriminal tersebut.

Dengan memperhatikan fakta seperti diatas, nampak bahwa penganiayaan dalam rumah tangga khususnya dalam hal ini penganiayaan oleh isteri terhadap suaminya, menunjukkan sifat kejahatan yang mulai meluas dan akan terus berlangsung sebagai bentuk akibat dari benyaknya kekerasan yang dilakukan oleh suami terhadap isteri sebelumnya. Sehingga harus mendapat perhatian dan penanganan yang serius oleh negara.

Dari perspektif inilah, penulis kemudian memberanikan diri menelusuri permasalahan tersebut melalui rangkaian penelitian dengan judul "Analisis Yuridis Kriminologis tentang Kekerasan Dalam Rumah Tangga yang Dilakukan oleh Isteri terhadap Suami" yang dimaksudkan untuk mengkaji fakta-fakta kriminologis sebagai entry point dalam rangka penanggulangan kekerasan dalam rumah tangga.

Penelitian ini, menelusuri fakta tentang bentuk-bentuk kekerasan yang dilakukan oleh isteri terhadap suami dan faktor-faktor kriminogen yang menyebabkan maraknya kekerasan dalam rumah tangga, serta upaya penanggulangan dan penegakan hukumnya. Jadi, penelitian ini mencoba untuk menelusuri bekerjanya tiga komponen hukum sebagai suatu sistem yang sangat berpengaruh terhadap ketertiban sosial, yaitu substansi hukum (legal substancy), struktur atau aparat pelaksana/ penegak hukum (legal structure), dan budaya hukum masyarakat (legal culture). Semuanya akan dipadukan untuk menemukan pembuktian sebagaimana dimaksud di atas.

Bertolak pada latar belakang di atas, dalam penelitian ini terdapat beberapa permasalahan pokok yang diteliti. Permasalahan tersebut dirumuskan sebagai berikut:

1. Bagaimana bentuk-bentuk kekerasan yang dilakukan oleh isteri terhadap suami? Penelusuran bentuk-bentuk kekerasan tersebut dimaksudkan untuk menganalisis apakah kekerasan yang dilakukan oleh isteri terhadap suami tersebut merupakan suatu tindak pidana (kejahatan) sebagaimana dimaksudkan dalam Undang-undang Penghapusan Kekerasan dalam Rumah Tangga dan peraturan hukum pidana lainnya, ataukah hanya merupakan bentuk reaksi negatif seorang isteri yang seringkali mendapat perlakuan kurang pantas dari seorang suami.

2. Faktor-faktor kriminogen yang menyebabkan terjadinya kekerasan oleh isteri terhadap suami. Faktor-faktor tersebut sangat penting untuk diteliti, mengingat tindak kekerasan yang dilakukan seorang isteri terhadap suami merupakan suatu fenomena yang sangat jarang terjadi, apalagi sampai menghilangkan nyawa seorang suami sendiri yang senantiasa memberikan nafkah lahir batin pada keluarga. 
3. Penegakan hukum terhadap isteri yang melakukan kekerasan terhadap suami. Dalam hal ini, bagaimana upaya penegakan hukum yang dilakukan penegak hukum terhadap seorang isteri (dan juga sebagai ibu yang harus merawat dan mengayomi anak-anaknya) tersebut. Haruskah keutuhan keluarga dan masa depan anak dikorbankan demi tegaknya sebuah Undang-undang Penghapusan Kekerasan dalam Rumah Tangga?

\section{METODE PENELITIAN}

Secara metodologis, penelitian yang dilakukan di Kota Malang ini merupakan penelitian hukum yuridis empirik yang mengkaji dari aspek kriminologis. Di mana pada penelitian ini menelaah faktor-faktor kriminogen dari terjadinya kekerasan oleh isteri terhadap suami dan menelaah realitas sosiologis yang terkait dengan penegakan hukum dalam rangka penanggulangan kekerasan dalam rumah tangga. Penelitian ini diarahkan pada analisis kualitatif, dan oleh karenanya, setiap langkah penelitian mulai dari studi teoritik, proses penelusuran data, pengolahan data, dan analisis data serta kelayakan sarana peneliti akan dilakukan triangulasi ${ }^{8}$ untuk menjamin kualitas hasil penelitian atas kompleksitas permasalahan ${ }^{9}$ yang terkait dengan kekerasan oleh isteri terhadap suami dan kekerasan dalam rumah tangga lainnya.

Pengumpulan data dalam penelitian ini dilakukan melalui penggabungan penelitian lapangan (field research) melalui wawancara mendalam (depth interview) pada responden yang sudah ditentukan secara nonrandom sampling mengingat tujuan dari penelitian (purpo-

${ }^{8}$ N.K. Denzin, The Research Act, McGraw Hill. New York, 1989.

9 Sudarwan Danim, Menjadi Peneliti Kualitatif, Pustaka Setia. Bandung, 2002, hal. 37 sive), dan dengan meneliti beberapa literatur dan dokumen-dokumen hukum yang dapat mendukung proses analisis data. Dalam pengumpulan data tersebut peneliti melakukan apa yang oleh Spradley dipahami sebagai penciptaan rapport yang dilakukan melalui 4 (empat) tahap, yaitu; apprehension, exploration, cooperation dan participation. Hal ini untuk meminimalisir keterasingan peneliti dengan para key informan dan atau responden penelitian dan sekaligus menjajaki fisibilitas untuk dapat bekerja sama.

Analisis data dilakukan dalam suatu proses, yang menurut Miles dan Huberman ${ }^{10}$ mensyaratkan peneliti bergerak dalam tiga siklus kegiatan, yakni reduksi data, penyajian data dan penarikan kesimpulan. Secara sistematis, proses analisis data dalam penelitian ini menggunakan teori Moleong ${ }^{11}$ dengan menelaah seluruh data yang diperoleh dari berbagai sumber, mereduksi data dengan cara membuat abstraksi, dan menyusunnya dalam satuan-satuan, yang kemudian data tersebut dikategorisasikan, untuk diuji keabsahaan data.

\section{HASIL DAN PEMBAHASAN} A. Kekerasan pada Umumnya dan Kekerasan
Dalam Rumah Tangga

Kekerasan diartikan dengan perihal yang berciri khas perbuatan seseorang yang menyebabkan cidera atau matinya orang lain atau menyebabkan kerusakan fisik orang lain/ paksaan. ${ }^{12}$ Dengan demikian adanya tindakan kekerasan dari pelaku menyebabkan timbulnya victim. Victim atau korban mempunyai arti yaitu orang-orang yang menderita secara jasmaniah

${ }^{10}$ M. B. Miles dan M. Huberman, Analisis Data Kualitatif, Penerbit UI Press, Jakarta, 1992, hal 120

1 Lexi J. Moleong, Metodologi Penelitian Kualitatif, Remaja Rosda Karya, Bandung, 2000, hal 190

${ }^{12}$ C.S.T. Kansil, Kamus Istilah Aneka Hukum. The Asia Fondation. Jakarta, 2001, hal 94

66 | Analisis Yuridis Kriminologis.. 
dan rohaniah sebagai tindakan diri sendiri atau orang lain yang bertentangan dengan kepentingan dan hak asasi yang menderita atau mengalami kerugian.

Menurut penjelasan ini, kekerasan itu merupakan wujud perbuatan yang lebih bersifat fisik atau penderitaan pada orang lain. Tidak ada satu orangpun yang mau untuk dilukai, tetapi Indonesia yang telah disepakati sebagai negara dengan masyarakat yang patriacal, dimana kaum lelaki memiliki peluang yang lebih besar untuk memegang kekuasaan atau kendali sehingga menyebabkan kekerasan yang dilakukan oleh kaum laki-laki tidak terlalu mendapat perhatian.

Kekerasan (violence) secara umum dapat diartikan sebagai suatu serangan terhadap fisik dan psikis serta integritas mental seseorang. ${ }^{13}$ Dalam hal ini, kekerasan bisa saja terjadi pada siapa saja, oleh siapa saja, di mana saja, dan kapan saja dan dengan alasan apa saja. Di antara beragam alasan yang memunculkan kejahatan tersebut, terdapat kekerasan yang dilakukan dalam lingku keluarga. Kekerasan dalam keluarga itulah yang kemudian melahirkan berbagai gerakan yang menuntut penghapusan kekerasan dalam rumah tangga.

Menurut Herkutanto, kekerasan bisa dilihat dari bentuk, tempat dan pelakunya. Dilihat dari bentuknya, bisa berupa kekerasan fisik maupun psikis, ditinjau dari segi tempat terjadinya, kekerasan fisik dan psikis bisa terjadi dalam lingkup rumah tangga dan di luar lingkup rumah tangga. ${ }^{14}$

13 Mansour Fakih, Analisis Gender dan Transformasi Sosial, Pustaka Pelajar. Yogyakarta, 1997, hal. 75

14 Herkutanto, Kekerasan terhadap Perempuan dan Sistem Hukum Pidana: Pendekatan dari Sudut Pandang Kedokteran, dalam Penghapusan Diskriminasi terhadap Wanita, Tapi Omas Ihromi (Ed.), Penerbit Alumni. Bandung, 2000, hal 263
Sedangkan batasan kekerasan dalam rumah tangga (KDRT) merupakan suatu batasan yang mengacu pada kekerasan yang terjadi pada lokus keluarga sehingga pelaku dan korban merupakan area yang sangat terbuka, dalam arti kata siapapun yang dapat di kategorikan sebagai anggota keluarga adalah pihak yang dapat dikategorikan pelaku atau korban kekerasan domestik ini. KDRT mencakup kekerasan terhadap anak, anggota keluarga yang lain dan bahkan pembantu rumah tangga, tetapi melihat beberapa hasil penelitian dan kasus yanga ada, fenomena kekerasan yang dilakukan oleh laki-laki atau suami terhadap perempuan atau isteri terbukti yang paling banyak terjadi.

Kekerasan dalam Rumah Tangga (selanjutnya disingkat KDRT) sebagaimana diatur dalam Pasal 1 angka 1 Undang-undang Nomor 23 Tahun 2004 tentang Penghapusan Kekerasan dalam Rumah Tangga adalah setiap perbuatan terhadap seseorang terutama perempuan, yang berakibat timbulnya kesengsaraan atau penderitaan secara fisik, seksual, psikologis, dan/atau penelantaran rumah tangga termasuk ancaman untuk melakukan perbuatan, pemaksaan, atau perampasan kemerdekaan secara melawan hukum dalam lingkup rumah tangga.

Spouse Abuse (penganiayaan terhadap isteri atau suami) adalah bagian dari family abuse atau family violence (kekerasan dalam keluarga) yang dapat berbentuk seperti family crime (kejahatan keluarga). Abuse adalah tindakan negatif yang dilakukan dengan kekerasan, dilakukan berulang-ulang dan berpola (maksudnya bahwa tindakan itu dapat berupa kekerasan, ucapan-ucapan yang menyakitkan) dan melalui proses sosisalisai dengan cara menghina, melukai, melecehkan, menyakiti dan dilakukan dengan sengaja. Pelakunya lebih kuat (power full) dan korbannya tidak mempunyai kekuatan dan tidak 
berdaya (power less). Tindakan agresif ini tidak berdiri sendiri tetapi ada sebab-sebab dan latar belakangnya, untuk spouse abuse (penganiayaan terhadap isteri atau suami) yang menjadi korban umumnya adalah wanita dewasa, tetapi tidak menutup kemungkinan bahwa yang menjadi korban adalah laki-laki. Hanya saja wanita lebih banyak menjadi spouse yang dianaiya baik korban tindak kekerasan berbentuk fisik, seksual, maupun psikis dari pada laki-laki. Memang tindakan penganiayaan merupakan salah satu aspek kehidupan yang tidak dapat di hindari. Dalam keluarga tindakan penganiayaan terhadap keluarga sampai saat ini masih merupakan kejahatan yang disembunyikan dan tidak di laporkan, karena bagi seorang perempuan atau isteri hal itu adalah wilayah pribadi.

Kekerasan dalam rumah tangga pada umumnya bisa dilakukan oleh siapa saja dan menimpa siapa saja dari anggota keluarga, bisa suami, isteri, saudara, anak, atau pembantu rumah tangga. ${ }^{15}$ Apabila ditinjau dari segi pelakunya, kekerasan fisik dan psikis dalam lingkup rumah tangga dapat dibedakan antara pelaku orang dewasa terhadap sesama dewasa (suami, isteri, pembantu), dan orang dewasa dengan anak-anak (orang tua terhadap anakanak atau sebaliknya).

Namun, meski kekerasan dalam rumah tangga bisa dilakukan oleh siapa saja, hasil penelitian terdahulu menunjukkan bahwa kekerasan dalam rumah tangga paling sering dialami oleh isteri. Disebutkan dari data yang ada, satu dari sepuluh wanita korban kekerasan adalah dilakukan oleh suami/pasangan hidupnya sendiri. Farha Ciciek juga mempunyai kesimpulan yang sama, bahwa secara umum pengertian KDRT lebih

\footnotetext{
${ }^{15}$ Kalibonso, Op. Cit. hal. 109

${ }^{16}$ Zulkarnain, Kajian Yuridis tentang Kekerasan Terhadap Isteri. Laporan Penelitian. DP3M Dikti, 2006
}

dipersempit artinya sebagai sebagai penganiayaan terhadap isteri oleh suami. Hal ini menurut Ciciek dapat dipahami karena dari kekerasan yang terjadi pada lingkungan rumah tangga kebanyakan korbannya adalah isteri.

Walau demikian, bukan berarti kekerasan yang dilakukan oleh isteri tidak pernah terjadi. Penelitian yang dilakukan Zulkarnain ${ }^{16}$ ternyata juga menemukan fakta bahwa beberapa isteri dihadapkan dalam proses peradilan kerana telah melakukan kekerasan terhadap suami maupun anggota keluarga yang lain.

\section{B. Pemberlakuan Undang-undang Penghapusan Kekerasan dalam Rumah Tangga di Indonesia}

Berawal dari pemikiran bahwa manusia merupakan serigala bagi manusia lainnya (homo homini lupus), selalu mementingkan diri sendiri dan tidak pernah memperhatikan keberadaan orang lain (meski keluarga sendiri), maka diperlukan suatu norma untuk mengatur kehidupannya. Hal ini menurut Topo Santoso $0^{17}$ sangat penting untuk menghindari perbuatan yang menyimpang, sehingga manusia yang satu tidak saling berkelahi dengan manusia lainnya. Karena tujuan dari norma adalah untuk ditaati, dan untuk ditaati diperlukan suatu sanksi yang dirumuskan secara tegas dan proporsional dalam peraturan perundang-undangan.

Penghapusan Kekerasan dalam Rumah Tangga adalah jaminan yang diberikan oleh negara untuk mencegah terjadinya kekerasan dalam rumah tangga, menindak pelaku kekerasan dalam rumah tangga, dan melindungi korban kekerasan (orang yang mengalami kekerasan atau ancaman kekerasan) dalam rumah tangga.

17 Topo Santoso dan Eva Ahjani Zulfa. Kriminologi, Rajawali Pers. Jakarta, 2003, hal. 3

68 I Analisis Yuridis Kriminologis.. 
Pemberantasan segala bentuk kekerasan dalam rumah tangga (criminal policy) bisa dilakukan dengan double track system yaitu dengan menggunakan penal policy dan non penal policy sekaligus. Hal itu dilakukan semata-mata untuk melindungi korban kekerasan dalam rumah tangga.

Pemberlakuan Undang undang Nomor 23 Tahun 2004 tentang Penghapusan Kekerasan dalam Rumah Tangga (PKDRT) merupakan bentuk penal policy. Urgensi pemberlakuan undang-undang tersebut tidak lepas dari dua isu pokok dalam penal policy. Dua isu pokok tersebut menurut Amrullah adalah; pertama, perlindungan terhadap calon korban (potential victim) agar tidak menjadi korban kekerasan dalam rumah tangga, dan kedua, perlindungan terhadap korban aktual (actual victim) agar mendapat keadilan atas perbuatan yang merugikan dirinya. ${ }^{18}$

Pemberlakuan undang undang PKDRT ini sebagai jawaban atas kekosongan hukum pidana dalam perlindungan korban kekerasan dalam keluarga. Selama ini, salah satu titik lemah dari penghapusan segala bentuk kekerasan dalam rumah tangga adalah tidak adanya payung hukum yang mengkriminalisasi segala bentuk kekerasan yang dilakukan salah satu anggota keluarga terhadap keluarga lainnya. Sebab kalau kondisi tanpa norma ini terus terjadi, maka secara kriminologis akan melahirkan berbagai bentuk kejahatan dengan dalih Anomi atau normlessness. ${ }^{19}$ Demikian yang disimpulkan dari hasil penelitian Haris

${ }^{18}$ Arief Amrullah, Politik Hukum Pidana dalam Rangka Perlindungan Korban Kejahatan, Bayu Media. Malang, 2003, hal. 12

${ }^{19}$ Dalam kajian kriminologi, terdapat salah satu teori yang melihat kejahatan terjadi karena faktor Anomi/normlessness atau kondisi tanpa norma, yang diperkenalkan oleh Emile Durkheim yang digunakan lebih lanjut untuk menjelaskan penyimpangan perilaku manusia (seperti KDRT: dari penulis) yang disebabkan karena persoalan ekonomi. Teori ini bahwa kekerasan dalam keluarga sulit ditanggulangi karena dasar hukum yang digunakan tidak akomodatif untuk persoalan kekerasan dalam keluarga. $^{20}$

\section{Bentuk-bentuk Kekerasan dalam Rumah Tangga}

Kekerasan dalam rumah tangga yang dilarang bagi setiap orang menurut Pasal 5 Undang-undang PKDRT bisa berupa kekerasan fisik, kekerasan psikis, kekerasan seksual dan kekerasan ekonomi (menelantarkan keluarga).

Kekerasan fisik sebagaimana dimaksud dalam Pasal 5 di atas adalah perbuatan yang mengakibatkan rasa sakit, jatuh sakit, atau luka berat atau bahkan bisa mengakibatkan matinya seseorang. Kekerasan semacam ini, paling sering terjadi dan dilakukan oleh seorang suami terhadap isteri atau orang tua terhadap anakanaknya. Menurut Fathul Jannah, ${ }^{21}$ beberapa korban kekerasan ini mengaku hampir setiap kali berbeda pendapat langsung mendapat pukulan dan penganiayaan dari suaminya.

Kekerasan psikis atau kekerasan psikologis adalah perbuatan yang mengakibatkan ketakutan, hilangnya rasa percaya diri, hilangnya kemampuan untuk bertindak, rasa tidak berdaya, dan/atau penderitaan psikis berat pada seseorang. Dalam beberapa penelitian, ditemukan bahwa akibat dari kekerasan psikis ini merupakan yang paling sulit untuk disembuhkan.

kemudian dikembangkan lebih jauh oleh Robert Merton (Atmasasmitha, 1992: 24-25) Bandingkan juga dengan Hagan (1987:164-165)

${ }^{20}$ Haris, Penganiayaan (Kekerasan) oleh Suami terhadap Isteri: Kajian terhadap Bentuk-bentuk/ Tipologi Penganiayaan Suami terhadap Isteri dan Faktor-faktor Penyebabnya di Kabupaten Sumenep. Lembaga Penelitian Universitas Muhammadiyah. Malang, 2004, hal 25

${ }^{21}$ Fathul Jannah (et.all) Kekerasan terhadap Isteri, tkis. Yogyakarta, 2002, hal 32 
Kekerasan seksual adalah pemaksaan hubungan seksual yang dilakukan terhadap orang yang menetap dalam lingkup rumah tangga tersebut, atau pemaksaan hubungan seksual terhadap salah seorang dalam lingkup rumah tangganya dengan orang lain untuk tujuan komersial dan/atau tujuan tertentu.

Sedangkan kekerasan ekonomi adalah bentuk kekerasan yang dalam undang-undang disebut sebagai bentuk menelantarkan angota keluarga. Melihat motif dari kekerasan ini, maka yang potensial melakukan kekerasan bentuk ini adalah suami. Penelitian menunjukkan bahwa seorang isteri yang bekerja sering kali mendapat perlakuan tidak wajar dari suami, dimana suami tidak mau memberi nafkah kepada isterinya dengan alasan isterinya sudah bekerja. Sehingga isteri harus menaggung seluruh kebutuhan keluarga, dan suaminya foya-foya.

\section{Penegakan Hukum terhadap Kekerasan dalam Rumah Tangga}

Berbicara efektifitas dalam penegakan hukum terhadap kekerasan dalam rumah tangga, maka tidak bisa lepas dari masalah keberadaan hukum sebagai suatu sistem. Karena hukummsebagai suatu sistem maka terdapat saling keterkaitan antara berbagai komponen sistem hukum. Lili Rasjidi mengemukakan beberapa komponenkomponen sistem hukum yang merupakan mata rantai yang saling terkait, yaitu: masyarakat hukum, budaya hukum, filsafat hukum, ilmu hukum, konsep hukum, pembentukan hukum, bentuk hukum, penerapan hukum, dan evaluasi hukum. Seluruh komponen-komponen sistem hukum tersebut sangat menentukan apakah hukum itu akan baik dan berjalan dengan baik pula. Apabila seluruh komponen sistem hukum (penghapusan kekerasan dalam rumah tangga) tersebut berjalan dengan baik, maka penegakan hukum berarti efektif, dan demikian juga sebaliknya. $^{22}$

Di sisi lain, hukum dapat berjalan dengan baik apabila didukung oleh tiga komponen yang dikemukakan oleh Robert Seidmean, yaitu: law making processes (proses pembentukan hukum oleh lembaga yang berwenang), law implementing processes (proses penerapan hukum oleh aparat penegak hukum, dan role occupant (kasadaran dan kepatuhan hukum oleh masyarakat). Ketiga komponen tersebut saling terkait dan tidak bisa dipisahkan. ${ }^{23}$ Dengan demikian maka kualitas dari produk hukum yang diberlakukan, in caso Undang-undang Nomor 23 Tahun 2004 tentang PKDRT menjadi faktor utama selain kualitas penerapan hukum oleh aparat dan peran masyarakat.

Memang, efektivitas penegakan hukum sedikit banyak tergantung pada faktor-faktor penegak hukumnya. Namun secara umum menurut Muladi, ${ }^{24}$ ada tiga faktor yang mempengaruhi efektivitas penegakan hukum. Pertama, adanya strategi penegakan hukum yang tepat dan dirumuskan secara komprehensif dan integral; kedua, adanya kehendak politik untuk melaksanakan strategi tersebut; dan ketiga, adanya pressure dalam bentuk pengawasan masyarakat. Yang terakhir inilah yang merupakan ranah publik untuk membantu mewujudkan penghapusan kekerasan dalam rumah tangga.

Beberapa komponen atau unsur-unsur dari sistem hukum dalam upaya penghapusan segala bentuk kekerasan dalam rumah tangga

${ }^{22}$ Lili Rasjidi dan Wyasa Putra, Hukum sebagai Suatu Sistem, Penerbit Mandar Maju. Bandung, 2003, hal. 152-176

2:" A. Mukthie Fadjar, "Penegakan Hukum, Korupsi dan Pemerintahan yang Bersih, dalam Jurnal WIDYA YURIDIKA Vol.9/No. 1/2001, FakuItas Hukum Universitas Widyagama, Malang, 2001, hal 16

${ }^{24}$ Muladi, Demokratisasi, Hak Asasi Manusia, dan Reformasi Hukum di Indonesia, The Habibie Center, Jakarta, 2002, hal 27 
di atas, dapat disederhanakan dengan mengacu pada konsep L. Friedman bahwa efektivitas dalam pelaksanaan sistem hukum bergantung pada tiga hal, yaitu: legal substancy, legal structure, and legal culture.

Secara praktis, penegakan hukum terhadap tindak kekerasan dalam rumah tangga ini diharapkan dapat berpengaruh terhadap sikap dan perilaku masyarakat di Indonesia yang sudah menjadikan kekerasan sebgai sebuah budaya, dimana sebagaimana digambarkan oleh Charles Sampford bahwa budaya hukum masyarakat sudah disorder, atau dalam bahasa hukum Indonesia disebut sebagai perilaku yang tidak taat norma. ${ }^{25}$

Secara khusus, terkait dengan upaya penghapusan kekerasan dalam rumah tangga, ada beberapa hal yang menjadi tolok ukur dalam menentukan efektivitas dari penegakan hukum ini, yaitu selain beberapa komponen yang dikemukakan di atas, bahwa keterbukaan dari korban kekerasan dalam rumah tangga juga menjadi sangat menentukan. Karena sikap yang memandang tabu untuk mengungkap aib keluarga ke publik, akan menghambat penegakan hukum dan utamanya upaya penghapusan segala bentuk KDRT. Disamping itu, keterlibatan pihak ketiga seperti LSM/NGO yang berperan sebagai pendamping yang diberi kewajiban sesuai pasal 15 UU PKDRT.

Masalah lain yang juga bisa mempengaruhi efektivitas dalam penegakan hukum terhadap adanya kekerasan dalam rumah tangga adalah masalah pembuktian. Di mana sudah kita sadari bahwa kekerasan dalam rumah tangga memiliki kekhasan, bahwa baik pelaku, korban dan saksi, sama merupakan satu keluarga yang memiliki hubungan darah. Khususnya apabila berdiri sebagai saksi, maka

\footnotetext{
${ }^{25}$ Charles Sampford, The Disorder of Law: a Critique of Legal Theory, Basil Blackwell Ltd., Oxford UK. 1989, hal 2
}

menurut Kitab Undang-undang Hukum Acara Pidana (KUHAP) seorang yang memiliki hubungan keluarga langsung dengan terdakwa (pelaku) tida dapat berdiri sebagai saksi. Dan pada sisi yang lain, KDRT seringkali terjadi secara tertutup (dalam arti hanya pelaku dan korban yang tahu), sehingga yang bisa berdiri sebagai saksi (mendengar, melihat, dan mengalami sendiri) hanyalah korban, sedangkan polisi atau LSM yang dilapori hanyalah sebagai testimonium de audito, padahal satu saksi dalam acara pidana tidaklah dianggap saksi, ulus testis nullus testis. ${ }^{26}$

\section{E. Faktor yang Mempengaruhi Terjadinya KDRT dan Upaya Penanggulangannya}

Sebelum memaparkan kajian teoritis tentang pananggulangan kekerasan dalam rumah tangga, harus diketahui dahulu mengapa kekerasan tersebut terjadi. Dengan mengetahui beberapa faktor yang mempengaruhi terjadinya kekerasan tersebut, maka upaya yang dilakukan dalam penanggulangan KDRT bisa lebih efektif.

Berbagai faktor banyak ditemukan dalam beberapa hasil penelitian maupun studi pustaka. Menurut Carl Heise dalam bukunya Violence Against Women: an Integrated, Ecological Framework sebagaimana dikutip oleh Mossas menjelaskan bahwa kekerasan dalam rumah tangga terjadi karena keterkaitan empat faktor, yaitu: ${ }^{27}$

a. Personal history, seperti misalnya tumbuh dan berkembang dalam rumah tangga yang penuh dengan kekerasan atau anak yang

${ }^{26}$ Zulkarnain, "Dilema Pembuktian Melalui Saksi dalam Penegakan Hukum terhadap Tindak Kekerasan dalam Rumah Tangga", Makalah dalam Kompetisi Peradilan Semu Berperspektif Gender antar Fakultas Hukum se-Jawa Timur, Tanggal 9-11 Desember 2004 di Universitas Surabaya. Surabaya, hal 5

27 R. Mossas, Pola Kebiasaan Turunan dari Keluarga atau Orang Tua, Pustaka Karya. Jakarta, 1992, hal 12 
memang mengalami kekerasan dari orang tuanya;

b. Microsystem, seperti dominasi figure pria dalam rumah tangga (termasuk figur pria adalah penguasa dan pengelola kekayaan keluarga) penggunaan alkohol, dan konflikkonflik perkawinan;

c. Exosystem, seperti status sosial, ekonomi rendah, penganguran dan pengaruh kenakalan lingkungan;

d. Macrosystem, seperti maskulinitas yang dipersepsikan sebagai dominan dan agresif, budaya patrialis, toleransi terhadap kekerasan.

Pola hubungan atau relasi antara suami dan iteri yang selama ini diposisikan suami sebagai subyek dan isteri sebagai obyek juga menjadi indikator penyebab kekersan dalam rumah tangga. Keputusan mutlak ada di tangan suami, jika isteri membangkang boleh dipukul. Intinya terjadi pola hubungan yang tidak simetris. Seharusnya baik suami, isteri, anak sama-sama harus berposisi sebagai subyek. Mansour Fakih juga menegaskan bahwa ketidak adilan gender dapat mengakibatkan marginalisasi, subordinasi, stereotype, kekerasan (tebal dari penulis), dan beban berlipat. $^{28}$

Dengan demikian, maka apabila terjadi kekerasan yang dilakukan oleh seorang isteri terhadap suami dikarenakan sebelumnya isteri tersebut telah mengalami tindak kekerasan dari seorang suami. Sehingga tindak kekerasan yang dilakukan isteri bisa dikatakan sebagai bentuk reaksi negatif korban atas kekerasan yang dialaminya. Dalam kajian kriminologi, hal tersebut bisa dikategorikan sebagai kriminalitas yang timbul karena adanya tekanan sebelumnya (strain theory). Dari konsep Strain Theory yang diperkenalkan oleh Robert Merton dapat disederhanakan bahwa seringkali dalam

${ }^{28}$ Mansour Fakih, Loc. Cit. keluarga, seorang saumi menentukan tujuan atau keinginan yang sama, tetapi tidak memberikan sarana dan kesempatan yang sama terhadap anggota keluarga lainnya. Sehingga dalam kondisi yang sudah abnormal, akan terjadi tekanan psikologis yang laur biasa dan bisa menjadikan yang bersangkutan bisa melakukan perbuatan yang menyimpang (delinquence behavior). ${ }^{29}$

Faktor ekonomi juga bisa menjadi faktor seorang isteri melakukan perbuatan menyimpang (kriminal) terhadap suami. Bilamana seorang sami sebelumnya menelantarkan (secara ekonomi) seorang isteri maka hal tesebut sudah merupakan bentuk KDRT. Sehingga seorang isteri bisa saja melakukan tindakan agresif terhadap suami sebagai bentuk protes atau ketidak puasan atas perlakuan suami.

Penelitian terdahulu juga mengungkapkan bahwa faktor yang mempengaruhi terjadinya kekerasan dalam rumah tangga, selain apa yang diungkapkan di atas, juga dipengaruhi oleh ketidak berdayaan hukum pidana positif di Indonesia yang kurang tegas mengatur mengenai kekerasan dalam rumah tangga. Misalnya, tidak ada pembatasan mengenai sampai batas-batas seperti apa kekerasan fisik yang dilakukan oleh suami terhadap isteri dapat ditoleransi sebagai bentuk pembinaan. UU PKDRT yang diharapkan mampu memberantas kekerasan dalam rumah tangga, ternyata kurang ampuh dan tidak banyak digunakan oleh penegak hukum sebagai dasar kriminalisasi terhadap kekerasan suami. Sementara KUHP hanya mengatur bahwa tindak pidana dalam keluarga (seperti KDRT) merupakan tindak pidana aduan yang harus ada

29 Dalam Topo Santoso dan E. A Zulva, Op. Cit. hal 61

72 |Analisis Yuridis Kriminologis. . 
pengaduan terlebih dahulu untuk bisa diproses berdasarkan hukum pidana. ${ }^{30}$

Selama ini, salah satu titik lemah dari penghapusan segala bentuk kekerasan dalam rumah tangga adalah tidak adanya payung hukum yang mengkriminalisasi segala bentuk kekerasan yang dilakukan salah satu anggota keluarga terhadap keluarga lainnya. Sebab kalau kondisi tanpa norma ini terus terjadi, maka secara kriminologis akan melahirkan berbagai bentuk kejahatan dengan dalih Anomi atau normlessness.

Upaya penanggulangan terhadap kekerasan dalam rumah tangga (dhi. kekerasan terhadap isteri), akan lebih efektif apabila mendasarkan pada pemberantasan kondisi/ faktor kriminogen yang ada. Apabila yang menjadi kriminogen dari terjadinya kekerasan dalam rumah tangga seperti yang diungkapkan oleh Carl Heise, Farha Ciciek, Mansour Fakih, dan Zulkarnain di atas, maka upaya penanggulangannya adalah bagaimana bisa membuang atau merubah pola sikap kriminogen dan peraturan hukum yang juga kriminogen seperti di atas tadi.

\section{F. Aspek Kriminologis dari KDRT yang Dilakukan Isteri Terhadap Suami}

Kekerasan dalam rumah tangga (KDRT) atau kekerasan dalam keluarga (domestic violence) sudah menjadi fenomena yang mencemaskan bagi kelangsungan kehidupan rumah tangga di Indonesia bahkan dunia, baik di negara sedang berkembang maupun negara maju sekalipun. Hal ini dikarenakan sulitnya membawa persoalan keluarga (domestik) ini pada persoalan publik yang melibatkan

3o Zulkarnain, Pemberlakuan Undang-undang Penghapusan Kekerasan dalam Rumah Tangga dan Efektivitas Penegakan Hukumnya. Lembaga Penelitian dan Pengabdian Masyarakat Universitas Widyagama Malang, 2005, hal 38 partisipasi masyarakat dan negara dalam memberantasnya, melalui peraturan perundang-undangan.

Dari hasil penelitian awal yang mengkaji Kekerasan Dalam Rumah Tangga (KDRT) sebagian besar memposisikan perempuan (isteri) dan anak-anak sebagai korban. Namun, pada sisi yang lain ternyata banyak diberitakan juga bahwa isteri telah melakukan kekerasan terhadap suami, bahkan sampai menyebabkan hilangnya nyawa suami. Fenomena tersebut sedikit membalik fakta bahwa dalam KDRT selalu menunjukkan suami sebagai pelakunya.

Data sebelumnya menyimpulkan bahwa tindak kekerasan terhadap perempuan merupakan fenomena serius yang dialami oleh banyak perempuan di Indonesia, dan institusi keluarga sebagai institusi terkecil dalam masyarakat, beberapa tahun terakhir ini dikatakan sebagai tempat paling rawan bagi munculnya tindak kekerasan terhadap perempuan. Kekerasan yang dilakukan suami terhadap isteri atau yang dikenal sebagai bentuk domestic violence adalah salah satu bentuk kekerasan terhadap perempuan yang banyak terjadi di masyarakat. Kekerasan domestik dalam rumah tangga, adalah setiap tindakan berdasarkan jenis kelamin, berakibat pada kesengsaraan dan penderitaan perempuan secara fisik, seksual dan psikologis termasuk ancaman tindakan tertentu, pemaksaan atau perampasan kemerdekaan secara sewenangwenang baik yang ada di depan umum atau dalam lingkungan pribadi. ${ }^{31}$

Banyaknya kasus kekerasan dalam rumah tangga yang terjadi menunjukkan adanya perubahan sosial yang perlu dikaji penyebabnya. Lebih-lebih pada beberapa tahun terakhir ini ketika persoalan krisis ekonomi melilit hampir seluruh rumah tangga di Indonesia. Khususnya di Malang (selanjutnya

${ }^{3}$ Zulkarnain, 2006, Op. Cit. hal 42 
menjadi lokasi penelitian ini) misalnya, pernah beberapa kali diberitakan terjadi tindak pidana yang dilakukan oleh anggota keluarganya sendiri. Beberapa bulan yang lalu, masyarakat Kota Malang digegerkan oleh ulah seorang ibu rumah tangga yang tega membunuh empat anaknya dan kemudian melakukan bunuh diri. Tahun sebelumnya sempat dimuat dimedia cetak, bahwa seorang isteri tega memotong alat kelamin suaminya karena suaminya diduga selingkuh dengan perempuan lain, dan masih banyak kasus serupa lainnya. Bahkan dalam penelitian Erdino ${ }^{32}$ di Kabupaten Bojonegoro Jawa Timur, selama dua tahun terakhir telah terjadi sedikitnya 4 kasus pembunuhan yang dilakukan oleh seorang isteri terhadap suami dengan berbagai alasan dan motif tindak pidananya.

Hal tersebut sungguh memprihatinkan, karena justru terjadi dalam lingkup keluarga yang semestinya harus hidup rukun damai berdasarkan ikatan lahir batin untuk menjadi keluarga yang harmonis. Persoalan lain yang menjadi dilema bahwa KDRT seringkali dianggap sebagai persoalan pribadi (domestik) yang harus diselesaikan secara pribadi pula antara mereka yang bertikai. Bahkan meskipun kekerasan ini sering mengakibatkan cacat atau meninggalnya korban, kasus tersebut biasanya dimasukkan sebagai kriminal biasa. Itu pun akan bisa diproses melalui jalur hukum apabila salah satu anggota keluarga yang dirugikan mengadukannya kepada kepolisian. Sementara yang terjadi, sangat jarang masyarakat yang melaporkan kekerasan dalam rumah tangga ini kepada polisi karena menganggap hal itu adalah persoalan pribadi keluarganya.

Penyebab utama dari kekerasankekerasan dalam rumah tangga adalah ketidakadilan gender yang menempatkan perempuan sub ordinat terhadap laki-laki,

s2 Erdino, Op. Cit. hal 44 sehingga isteri dianggap milik suami "mens property ${ }^{33}$ Pendapat ini didasarkan pada anggapan bahwa laki-laki bukan hanya pencari nafkah keluarga tetapi juga karena memang sudah haknya demikian, oleh karena itu lakilaki dianggap sah dan berhak memperlakukan isteri sekehandak hatinya. Kondisi sosial budaya semacam itu terus menerus bertahan pada masyarakat, sehingga walaupun seseorang perempuan bekerja atau pun berpendidikan lebih tinggi, kedudukannya tetap sub ordinat yang berarti harus melayani suami dan keluarga, serta berhak di perlakukan semaunya.

\section{PENUTUP}

Kekerasan Dalam Rumah Tangga merupakan fenomena serius yang harus ditanggulangi dengan baik. Bahkan sudah mulai lebih memprihatinkan, karena bukan lagi lelaki sebagai nominasi tertinggi sebagai pelaku KDRT, melainkan juga isteri. Sehingga pemberlakuan undang-undang yang melarang praktek kekerasan dalam lingkup keluarga tersebut menjadi sangat urgen. Dari pembahasan hasil penelitian yang dipaparkan pada bab terdahulu, dapat disimpulkan beberapa hal sebagai berikut:

1. Kebijakan pemberlakuakn UU PKDRT tersebut untuk mengisi ketiadaan perundang-undangan pidana yang mengatur perlindungan korban kekerasan dalam lingkup rumah tangga, memang dirasa sangat perlu. Tetapi secara $a$ contra rio malah memicu lahirnya kekerasan modus baru dalam lingkup rumah tangga, yaitu munculnya KDRT yang dilakukan oleh isteri terhadap suami dan keluarga

ss Indriyati Suparno dan Agung Ratih K., Persepsi, Pengethauan Perempuan dan Gambaran Situasi Kekerasan Terhadap Isteri: Studi pada Masyarakat Eks Karisidenan Solo. Solidaritas Perempuan untuk Kemanusiaan dan HAM dan Civil Society Support and Strenghtening Program. Surakarta, 2002, hal 3

74|Analisis Yuridis Kriminologis. . 
lainnya. Bentuk bentuk kejahatan yang dilakukan oleh isteri terhadap suami tersebut pun sangat bervariatif.

2. Dalam kajian kriminologi, banyak hal yang dapat menyebabkan terjadinya KDRT yang dilakukan oleh isteri. Tetapi apabila dianalisis lebih jauh (khususnya jika memekai teori causaliteit dalam hukum pidana, maka sebenarnya kekerasan yang dilakukan oleh isteri tidak lebih sebagai bentuk reaksi negatif atas kekerasan yang dilakukan oleh suami sebelumnya.

3. Terhadap beberapa fenomena di atas, maka pada tataran law enforcement-nya harus lebih mengedepankan aspek sosiokriminologis dalam mewujudkan keadilan yang berbasis pada individualisasi pidana. Mempidana seorang ibu rumah tangga (isteri) sebagai bentuk tindakan represif atas KDRT yang dilakukan justru menutupi bentuk-bentuk KDRT yang sesungguhnya, dimana sebagian besar dilakukan oleh suami.

$$
-000-
$$

\section{DAFTAR PUSTAKA}

Amrullah, Arief. 2003. Politik Hukum Pidana dalam Rangka Perlindungan Korban Kejahatan, Bayu Media. Malang

Anonim, 2007. "Geger: Ibu Racuni 4 Anaknya lalu Bunuh Diri". Dalam Jawa Pos Edisi 12 Maret 2007

1999. Population Report, Ending Violence Against Women, serial L (11). The Center for Helath and Gender Equity (CHANGE). Maryland

Atmasasmita, Romli. 1992. Teori dan Kapita Selekta Kriminologi. PT Eresco. Bandung

Ciciek, Farha. 1999. Ikhtiar Mengatasi Kekerasan dalam Rumah Tangga. LKAJ-PSP-The Asia Fondation. Jakarta

Danim, Sudarwan. 2002. Menjadi Peneliti Kualitatif, Pustaka Setia. Bandung
Denzin, N.K. 1989. The Research Act, McGraw Hill. New York

Fadjar, A. Mukthie. 2001. "Penegakan Hukum, Korupsi dan Pemerintahan yang Bersih, dalam Jurnal WIDYA YURIDIKA Vol.9/No. 1/2001, Fakultas Hukum Universitas Widyagama, Malang

Faisal, Sanapiah, 1990. Penelitian Kualitatif: Dasar-dasar dan Aplikasi, Yayasan Asah Asih Asuh, Malang

Fakih, Mansour. 1997. Analisis Gender dan Transformasi Sosial, Pustaka Pelajar. Yogyakarta 2000. Kekerasan Gender dalam Pembangunan, dalam Kekerasan dalam Perspektif Pesantren, Ahmad Suaedy (Ed.). Grasindo-P3M. Jakarta

Gelles, R.J. 1995. Volence in The Family: A Review of Research in The Seventies. dalam Journal of Mariage and the Family.

Hadikusuma, Hilman. 1995. Metode Pembuatan Kertas Kerja atau Skripsi Ilmu Hukum, Mandar Maju, Bandung

Hagan, John. 1987. Modern Criminology: Crime, Criminal, Behavior, and Its Control. McGraw-Hill Book Company. Toronto

Haris. 2004. Penganiayaan (Kekerasan) oleh Suami terhadap Isteri: Kajian terhadap Bentuk-bentuk/Tipologi Penganiayaan Suami terhadap Isteri dan Faktor-faktor Penyebabnya di Kabupaten Sumenep. Lembaga Penelitian Universitas Muhammadiyah. Malang

Herkutanto. 2000. Kekerasan terhadap Perempuan dan Sistem Hukum Pidana: Pendekatan dari Sudut Pandang Kedokteran, dalam Penghapusan Diskriminasi terhadap Wanita, Tapi Omas Ihromi (Ed.), Penerbit Alumni. Bandung

Jannah, Fathul (et.all). 2002. Kekerasan terhadap Isteri, LkiS. Yogyakarta

Kalibonso, 2000. "Kekerasan terhadap Perempuan dalam Rumah Tangga sebagai Pelanggaran Hak Asasi Manusia" dalam Luhalima (Ed.) Pemahamam terhadap Bentuk-bentuk Kekerasan terhadap Perempuan dan Alternatif Pemecahannya. Kelompok Kerja Convention Watch Pusat Kajian Wanita dan Fewleral. Jakarta 